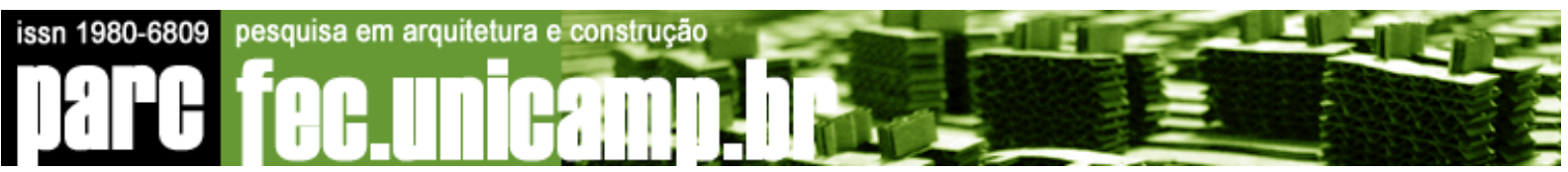

\title{
Diretrizes Urbanísticas e Construtivas para Cidades de clima Semi-árido
}

\author{
Guidelines for town planning and construction in towns with semi-arid climate
}

\author{
MARIANA BRITO DE LIMA \\ EDSON LEITE RIBEIRO
}

Arquiteta e Urbanista, pela Universidade Federal do Rio Grande do Norte, Mestre em Engenharia Urbana pelo Programa de Pós- Graduação em Engenharia Urbana e Ambiental da UFPB. mariana@ifto.edu.br

Arquiteto e Urbanista, Mestre em Desenvolvimento Urbano pela UFPE, Doutor em Engenharia Civil pela USP, Professor Dr. do DA/CT/UFPB.

edson@ct.ufpb.br

\section{Resumo}

O estudo sobre o clima urbano de uma região é essencial para a compreensão dos problemas ambientais resultantes da sua urbanização. $O$ objeto de estudo desta pesquisa se inscreve no contexto de interação entre fenômenos da urbanização e o clima das cidades, especificamente a cidade de Monteiro, localizada em uma região de clima semi-árido, no Estado da Paraíba. Portanto, a questão que se coloca como problema é a de como elaborar o planejamento urbano e arquitetônico em cidades de clima semi-árido, que atendam as necessidades do conforto ambiental para o ser humano. Após analisar as configurações do clima urbano estudado e correlacionar os problemas que podem ter influenciado o clima em cada ponto de estudo, são indicadas algumas diretrizes urbanísticas e construtivas, de forma a auxiliar na melhoria do conforto ambiental na cidade de Monteiro/PB.

Palavras Chave: Clima urbano, análise bioclimática, semi-árido, cidades de pequeno porte.

\begin{abstract}
In order to adequate town planning and architecture to the climate in a certain place it is necessary to build spaces that offer comfortable conditions for human beings. As the hot and dry climate presents more challenges regarding higrotermic comfort in the environment, it implies a major need to create micro-climates and, thus, town planning and construction solutions that ease the climatic conditions and attend human needs of environmental comfort. To be able to understand the environmental problems that result from the town planning in a certain region it is essential to study the urban climate in that region. After having analyzed the configurations of the urban climate in question and having correlated the possible problems that can have influenced the climate in every measuring point, the study indicates guidelines for town planning and constructions that can improve the environmental comfort in the town of Monteiro.
\end{abstract}

Key Words: Urban Climate; bioclimatic analysis; semi-arid; small cities. 


\section{Diretrizes Urbanísticas e Construtivas para Cidades de clima Semi-árido}

\section{Introdução}

Adequar o urbanismo e a arquitetura ao clima de um determinado local significa construir espaços que possibilitem ao homem condições de conforto. O clima quente e seco, por apresentar maiores adversidades quanto ao conforto higrotérmico do ambiente, implica uma necessidade maior de criação de microclimas e, portanto, adaptações urbanísticas e construtivas que amenizem e atendam o ser humano no que diz respeito ao conforto ambiental. Nesse sentido, este artigo pretende apresentar os resultados de pesquisa realizada durante a dissertação de mestrado, intitulada "Diretrizes urbanísticas e construtivas para cidades de clima semi-árido: Estudo de Caso na Cidade de Monteiro".

A definição do objeto de estudo desta pesquisa se inscreve no contexto de interação entre fenômenos da urbanização e o clima das cidades, especificamente a cidade de Monteiro, localizada em uma região de clima semi-árido, no Estado da Paraíba. A questão a ser investigada consiste em como elaborar o planejamento urbano e arquitetônico em cidades de clima semi-árido, que atendam as necessidades do conforto ambiental para o ser humano.

No intuito de responder essa questão foi realizada uma pesquisa de campo, utilizando cinco estações climatológicas portáteis distribuídas em regiões distintas da cidade, as quais mediram a velocidade e direção dos ventos, temperatura e umidade relativa do ar, durante o mês de novembro, mês historicamente considerado o mais quente do ano. Os dados climáticos e as variáveis ambientais da cidade, tais como uso do solo, densidade, arborização, orientação das vias, entre outras, foram estudadas seguindo a metodologia proposta por Monteiro (1976) e Bustos Romero (2001).

$\mathrm{Na}$ primeira fase do estudo, os dados climáticos de cada ponto de medição escolhido foram comparados externa e internamente, no intuito de compreender de que forma a edificação e seu entorno contribuem para a amenização das variáveis climáticas internas em cada edificação. A segunda fase da pesquisa analisou comparativamente os dados de todos os pontos em relação aos dados climáticos da estação agrometeorólogica mais próxima, localizada no município vizinho, Sertânia (PE).

Após analisar as configurações do clima urbano estudado e correlacionar os problemas que podem ter influenciado o clima em cada ponto de estudo obteve-se como resultado algumas diretrizes urbanísticas e construtivas, visando auxiliar na melhoria do conforto ambiental na cidade de Monteiro (PB). 


\section{Caracterização da área de estudo - Clima}

O município de Monteiro (PB) tem um clima semi-árido quente e seco (Bsh) com chuvas de verão, segundo a classificação de W. Köeppen. É o clima típico de toda a mesorregião. As chuvas sobre o semi-árido paraibano apresentam-se com melhor distribuição temporal e espacial a partir do mês de fevereiro, quando a Zona de Convergência Intertropical, principal sistema meteorológico gerador de chuvas nesse setor, passa a atuar com maior ênfase.

O clima semi-árido é melhorado na área pela altitude, tornando-o mais ameno, com precipitação pluviométrica oscilando entre $483 \mathrm{~mm}$ e $800 \mathrm{~mm}$ anuais e temperatura variando entre 18 a $38^{\circ} \mathrm{C}$. A caracterização climática do município estudado tem como base os dados do Atlas Climatológico da Paraíba (1987), que reúne os dados climáticos recolhidos por mais de 50 anos. De acordo com o mesmo Atlas, o município apresenta temperaturas médias máximas de $30,1^{\circ} \mathrm{C}$ e mínimas de $17,4^{\circ} \mathrm{C}$, sendo a temperatura média $23,37^{\circ} \mathrm{C}$ (GRÁFICO 1)

O mês que apresenta maior queda na temperatura é o mês de maio, sendo o mês de novembro considerado historicamente o mês mais quente e por este motivo o escolhido para a coleta de dados da pesquisa de campo. O período de chuvas acontece durante os meses de fevereiro a maio e o mês de março, segundo o Atlas citado, é o que concentra o maior índice de precipitação (GRÁFICO 2). Os valores mensais da umidade relativa do ar variam de $61 \%$ a $78 \%$ nos meses de novembro e junho, respectivamente, apresentando uma média anual de 70\% (GRÁFICO 3).

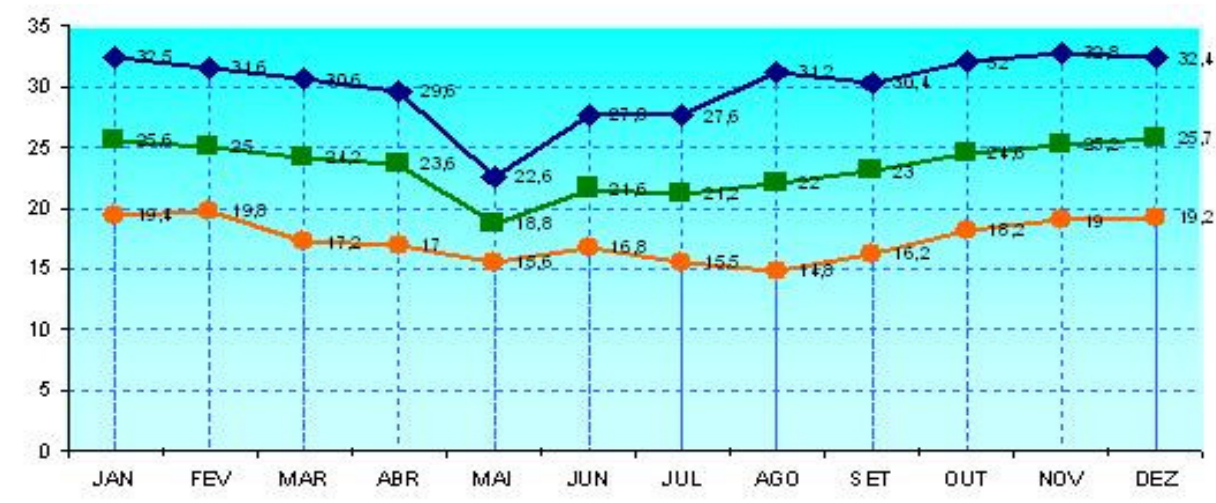

—Temperatura Máxima $\left({ }^{\circ} \mathrm{C}\right) \longrightarrow$-Temperatura Média $\left({ }^{\circ} \mathrm{C}\right) \longrightarrow$ Temperatura Mínima $\left({ }^{\circ} \mathrm{C}\right)$

| GRÁFICO 1: Temperaturas médias mensais dos valores diários em Monteiro_(PB) no período 1913 - 1967. Fonte: Atlas Climatológico do Estado da Paraíba, 1987. 

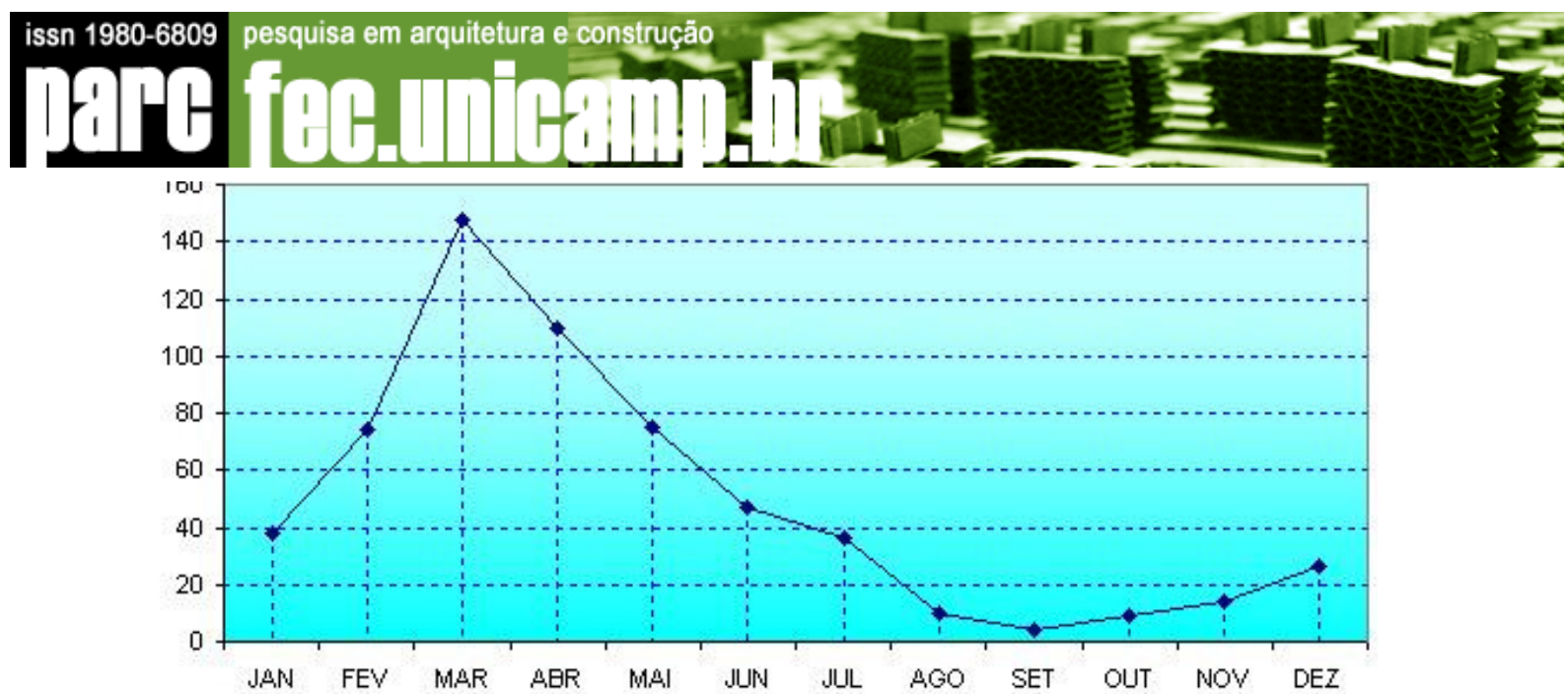

$\rightarrow-$ Precinitacẫo Média Mensal (mm)

GRÁFICO 2: Médias mensais da precipitação em um período de 54 anos no município de Monteiro (PB). Fonte: Atlas Climatológico do Estado da Paraíba, 1987.

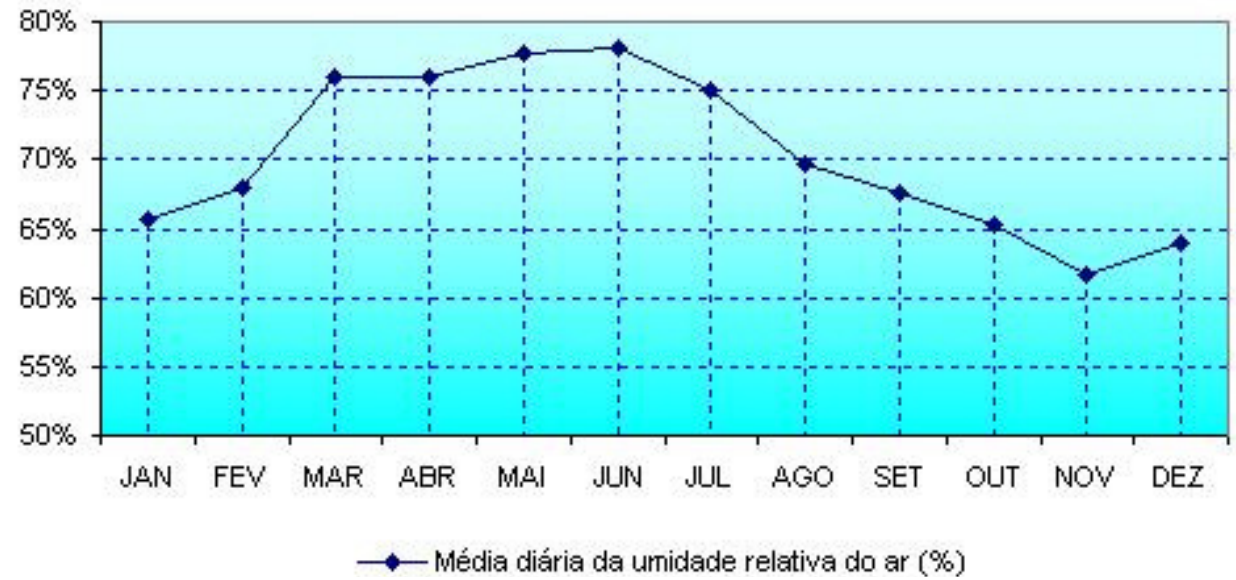

GRÁFICO 3: Valores médios mensais da Umidade relativa do ar (\%) em Monteiro (PB) período de 25 anos. Fonte: Atlas Climatológico do Estado da Paraíba, 1987.

\section{Caracterização da área de estudo - Evolução e Ocupação do Solo Urbano do Município}

Monteiro ganhou o status de município em 1872. Seu povoamento antecede o ano de 1840, localizando-se às margens do Rio Paraíba. O maior adensamento de Monteiro ocorreu durante a década de 1950, devido ao desenvolvimento da economia do algodão (FIGURA 1 e FIGURA 2). A cidade ainda conserva um grande número de edificações da primeira metade do século $\mathrm{XX}$, em sua maioria de estilo Eclético.

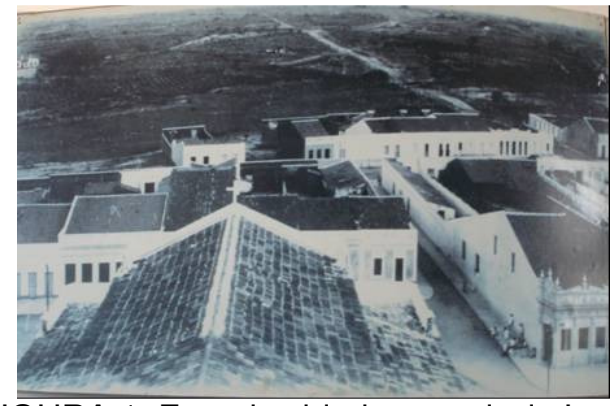

FIGURA 1: Foto da cidade a partir da Igreja Matriz na década de 1920. Fonte: Museu Histórico de Monteiro, 2005.

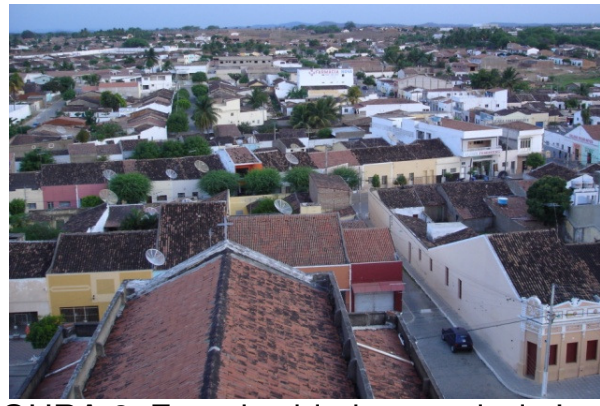

FIGURA 2: Foto da cidade a partir da Igreja Matriz em 2006. Autora: Lena Zetterström, 2006. 


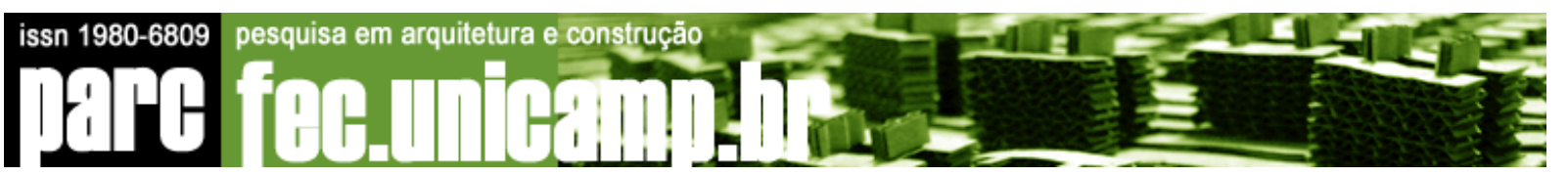

$\mathrm{Na}$ área central da cidade as casas não apresentam recuos laterais e frontais, como ocorre na maioria das cidades brasileiras do período (FIGURA 3). A calha viária das vias principais é altamente reflexiva de luz e reemissora de calor (FIGURA 4). A topografia da cidade é predominantemente plana, variando cerca de 30m entre as cotas 610 e 580 no sentido Sudeste-Noroeste. Seu núcleo urbano ainda possui um açude cercado por uma área não urbanizada (FIGURA 5) e uma sede da fazenda da EMBRAPA, sendo estas as duas grandes concentrações de áreas verdes na cidade. O corpo de água que cerca a cidade, formado pelo Rio Paraíba, conserva resquícios de mata ciliar em uma de suas margens (FIGURA 6).

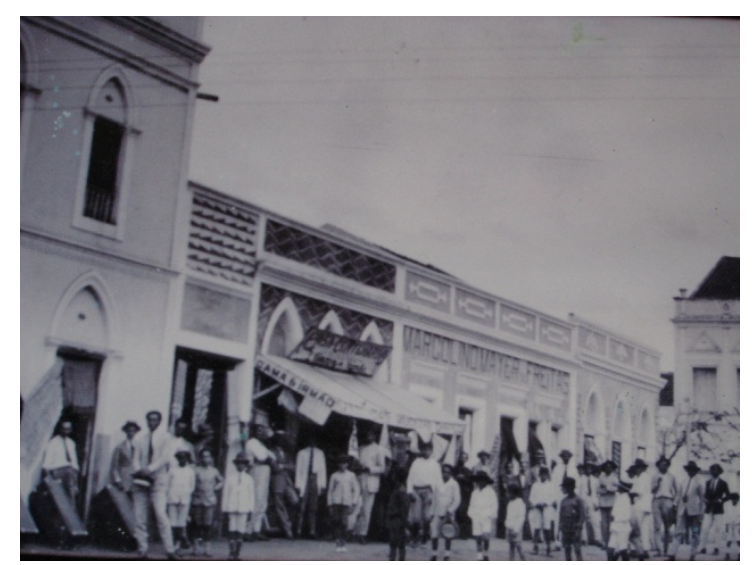

FIGURA 3: Foto de Monteiro na década de 1920. Fonte: Museu Histórico de Monteiro, 2005.

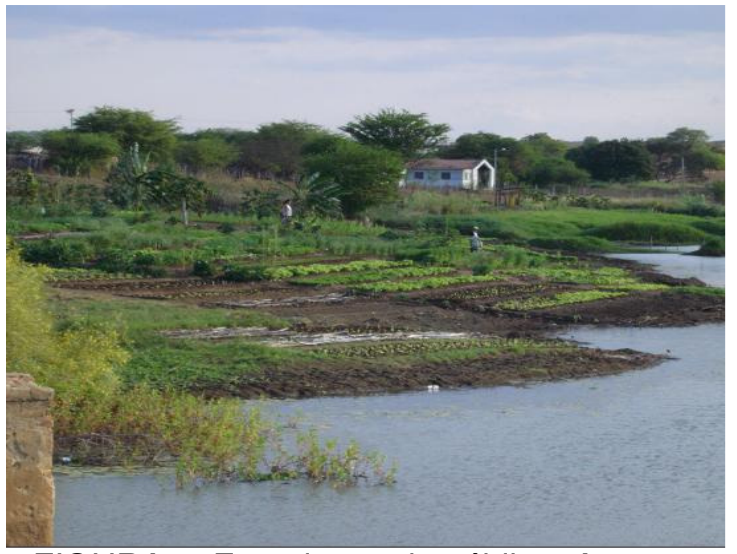

FIGURA 5: Foto do açude público. Autora: Mariana Lima, 2005.

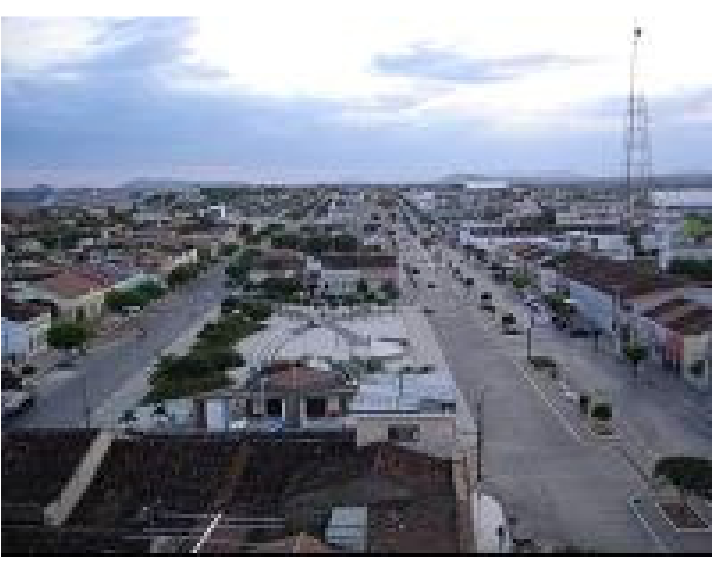

FIGURA 4: Foto das avenidas principais e Praça João Pessoa. Autora: Lena Zetterström, 2005.

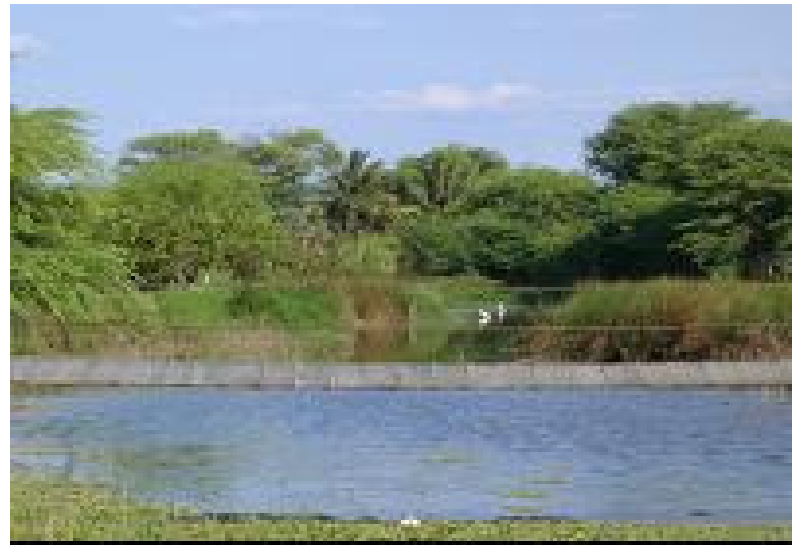

FIGURA 6: Foto do Rio Paraíba. Autora: Mariana Lima, 2005.

\section{Caracterização da área de estudo - Desenho Urbano}

Monteiro cresceu limitada pelo Rio Paraíba, que se impõe como uma barreira natural à sua expansão. Este fato condicionou o crescimento da cidade em direção oposta ao rio. A forma urbana de Monteiro caracteriza-se pela ausência de grandes barreiras físicas, excetuando-se o Rio, e por um traçado urbano ortogonal (FIGURA 7 e FIGURA 8), com maior adensamento na Zona Central. No centro, o núcleo principal é composto por quatro praças e quatro ruas que cortam o eixo central da cidade de cerca 


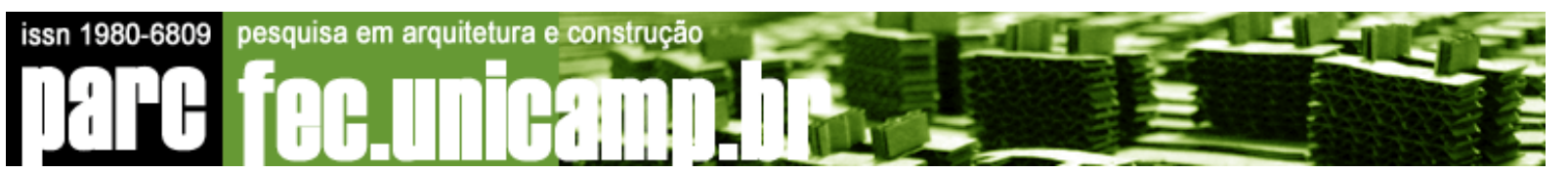

de $2 \mathrm{~km}$ no sentido sudoeste-nordeste. As larguras viárias principais variam entre 12 e 25 metros, com pavimentação em paralelepípedo. A ocupação é mais diluída em torno dos eixos viários principais.

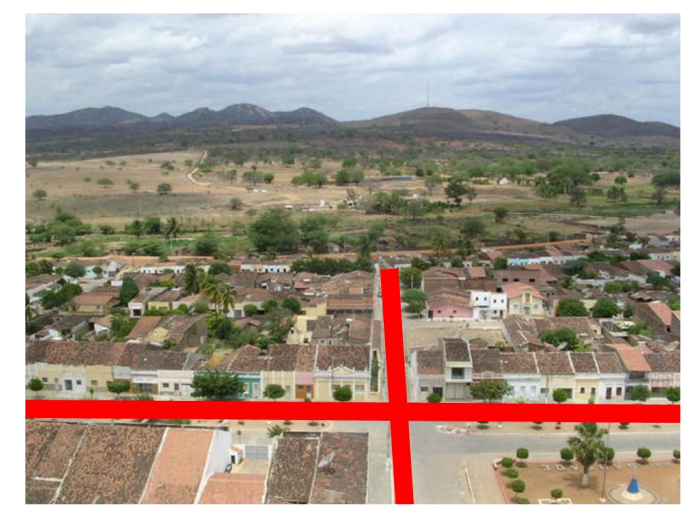

FIGURA 7: Foto do Traçado Ortogonal. Autor: Ricardo Cardoso, 2005.

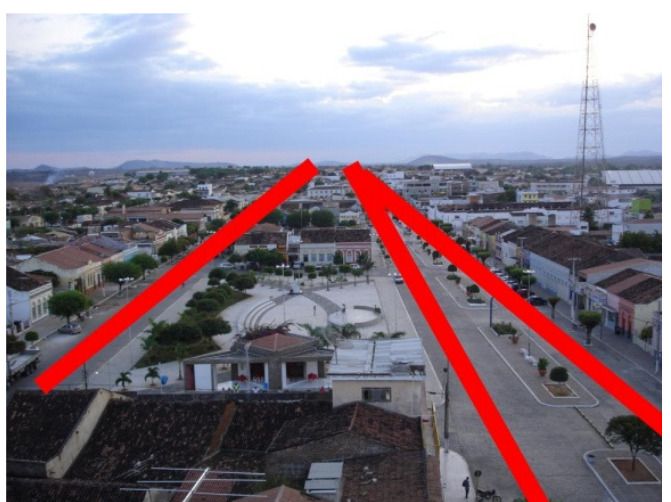

FIGURA 8: Foto dos Eixos Principais de Monteiro. Autor: Ricardo Cardoso, 2005.

A paisagem das ruas centrais é caracterizada pela moldura das fachadas idênticas e homogêneas em escala e tipologia, pois a maioria segue o mesmo padrão arquitetônico (FIGURA 9). Mas esta paisagem está sendo degradada pela colocação de placas de comércio e pelas reformas nas edificações que estão descaracterizando o patrimônio arquitetônico (FIGURA 10).

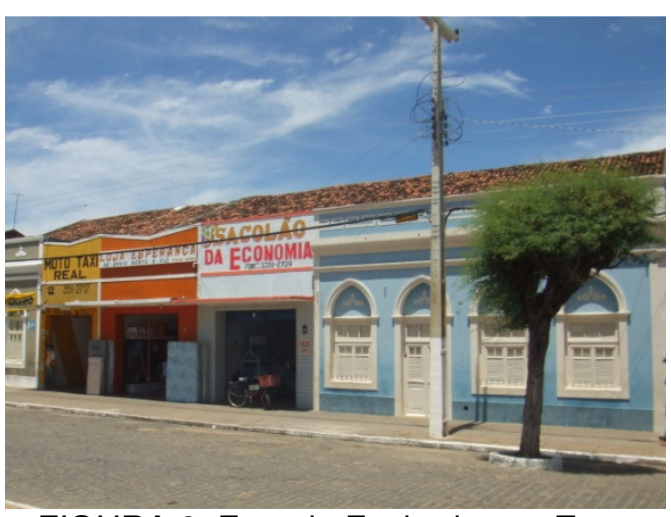

FIGURA 9: Foto de Fachadas na Zona Comercial. Autora: Mariana Lima, 2006.

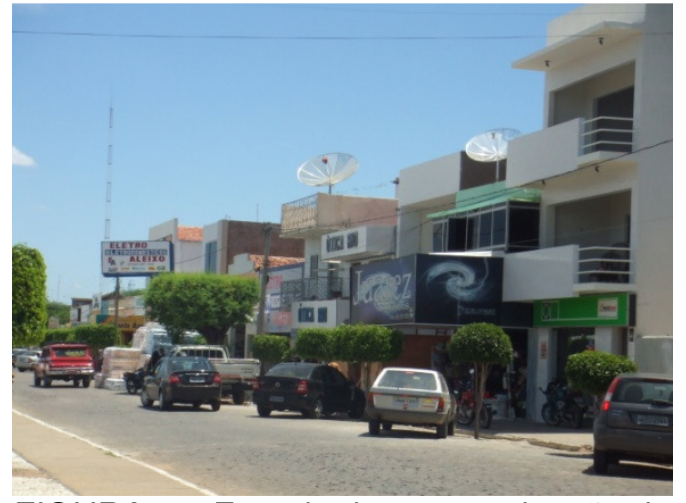

FIGURA 10: Foto de descaracterização de fachadas. Autora: Mariana Lima, 2006.

Em relação à estrutura viária central nota-se que a largura das ruas e avenidas são adequadas para suportar o tráfego de veículos e pedestres. Os bairros adjacentes à Zona Central possuem traçado semelhante, seguindo perpendicularmente às vias principais. $\mathrm{Na}$ zona periférica, de urbanização mais recente, a aparência das ruas demonstra baixa qualidade de desenho, condições pouco acolhedoras devido à descontinuidade de passeios, má pavimentação, além da espacialização confusa, sem condições de conforto ambiente para os moradores ou passantes. Os bairros populares carecem de configuração física relevante, ordenação e regulamentação através de códigos de obras e posturas para conter as construções espontâneas e desordenadas que prejudicam o 
conforto e a leitura da cidade. Esse desenho urbano, na periferia, tem produzido ruas socialmente desagregadoras e climatologicamente desconfortáveis.

\section{Caracterização da área de estudo - Tipologia Habitacional}

O padrão habitacional predominante é do tipo popular na maioria dos bairros, destacando-se habitações de famílias de classe média e de classe baixa. Atualmente, verificam-se várias tipologias habitacionais em Monteiro, conforme o QUADRO 1:

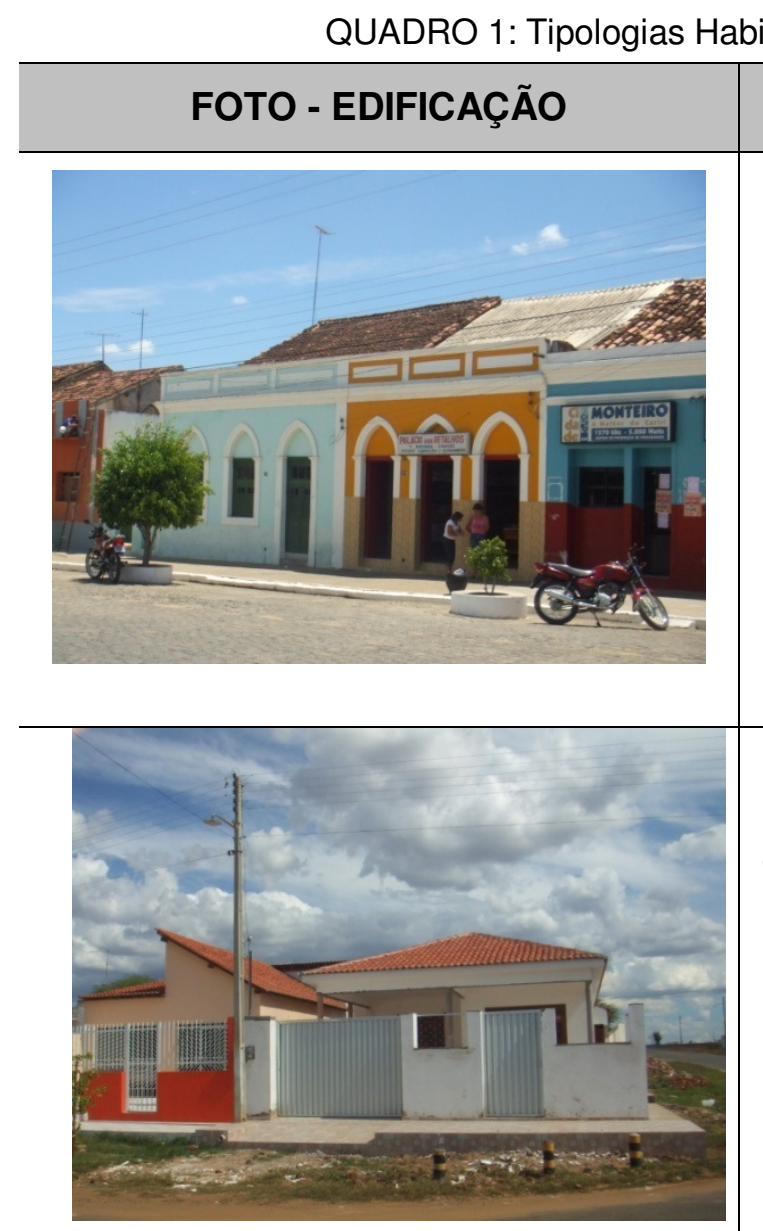

TIPOLOGIA ARQUITETÔNICA

Moradia unifamiliar situada na Zona Central, através de casas justapostas com estilo arquitetônico eclético, com alinhamento no passeio, em quadras compostas por uso misto, localizadas na área denominada de Centro

Histórico;

FIGURA 11: Foto de edificações no estilo Eclético. Autora: Mariana Lima, 2006.

Moradias unifamiliares em residências com recuo, com estilo contemporâneo, no padrão de classe média;

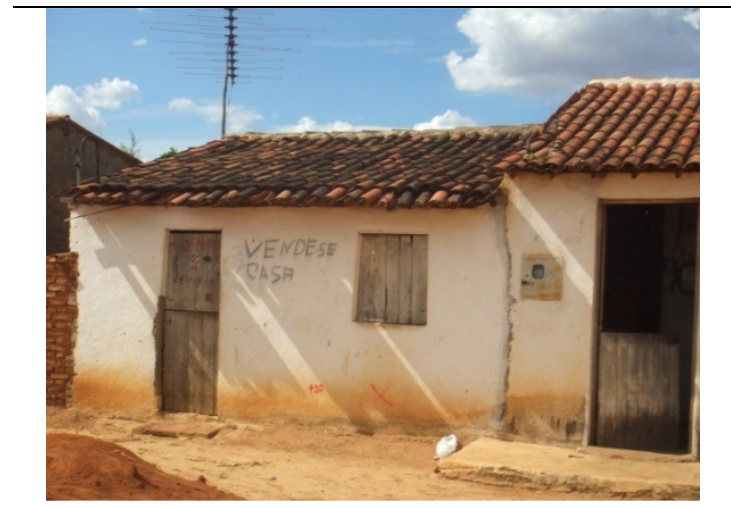

FIGURA 12: Foto de Edificação contemporânea. Autora: Mariana Lima, 2006.

Moradias populares de uso unifamiliar, de padrão baixo, em loteamentos periféricos e conjuntos habitacionais;

FIGURA 13: Foto de Edificação de baixo padrão. Autora: Mariana Lima, 2006. 

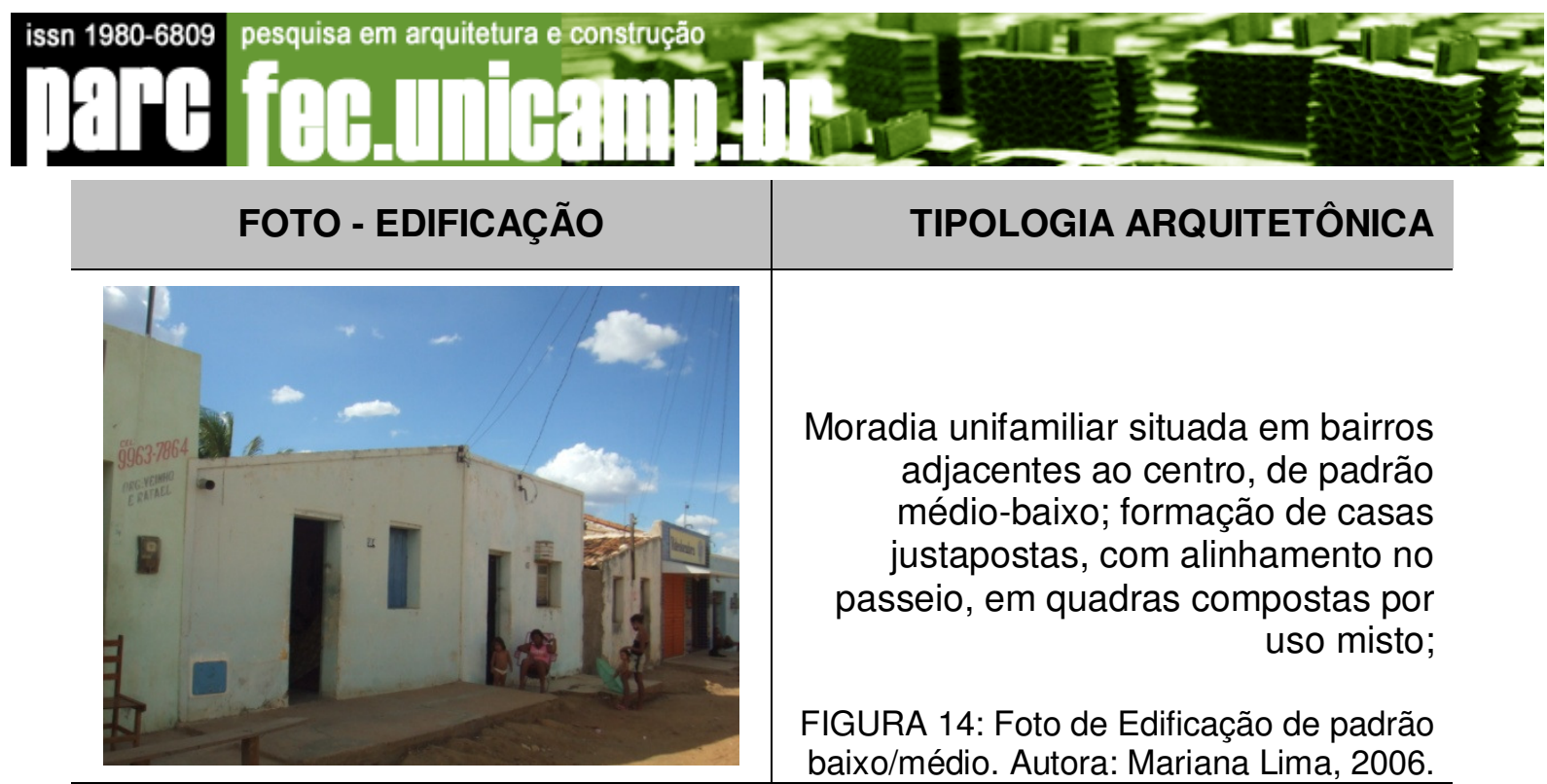

TIPOLOGIA ARQUITETÔNICA

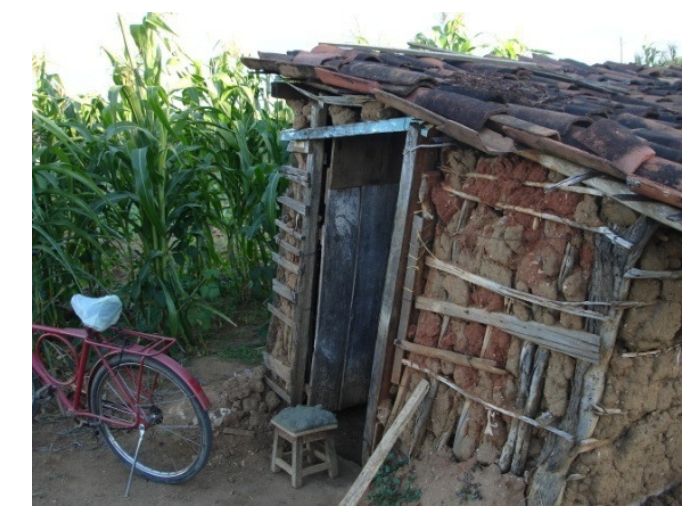

Moradia unifamiliar situada em bairros adjacentes ao centro, de padrão médio-baixo; formação de casas justapostas, com alinhamento no passeio, em quadras compostas por uso misto;

FIGURA 14: Foto de Edificação de padrão baixo/médio. Autora: Mariana Lima, 2006.

Moradias precárias em áreas de risco e invasões, do tipo favelas.

FIGURA 15: Foto de Moradia Precária. Autora: Mariana Lima, 2006.

\section{Métodos e Técnicas de pesquisa}

A metodologia adotada na pesquisa teve como base a Teoria do Sistema Clima Urbano (MONTEIRO, 1976). Para os propósitos desta pesquisa este é o referencial teórico adequado, uma vez que permite a elaboração de diretrizes urbanísticas e construtivas para cidades de clima semi-árido. Com o objetivo de auxiliar a elaboração de medidas voltadas a ordenar o crescimento urbano da cidade de Monteiro propõem-se as seguintes questões: até que ponto a forma urbana influencia a formação de microclimas diferenciados na área objeto de estudo? Existem diferenças nas variáveis ambientais entre as regiões mais densamente construídas?

Buscando respostas a estas questões, optou-se por utilizar a metodologia de análise do clima urbano, conforme a proposta teórica de Carlos Augusto de Figueiredo Monteiro (1976; 2003), citada anteriormente, e a metodologia de análise bioclimática estruturada por Bustos Romero (2001). Outros autores, como Araújo (2001), Grimm (1999), Frota (2003) Olgyay (1963), Givoni (1967, 1992), e Roaf (2006), foram estudados de forma complementar, seguindo o objetivo de apresentar uma análise coerente da cidade e assim traçar as diretrizes almejadas nesta pesquisa. Desta forma, incluíram-se alguns aspectos de morfologia urbana e foram confeccionados diagramas solares e diagramas de ventos para cada ponto (ou local) estudado. 
No desenvolvimento da pesquisa foram utilizados os seguintes procedimentos: revisão da literatura pertinente, utilização de softwares, levantamento de dados climáticos, análise do clima urbano, análise bioclimática, caracterizações complementares, uso de diagrama solar e dos ventos, a partir de dados e informações levantadas. Esses procedimentos são mostrados no fluxograma (FIGURA 16) e especificados a seguir:

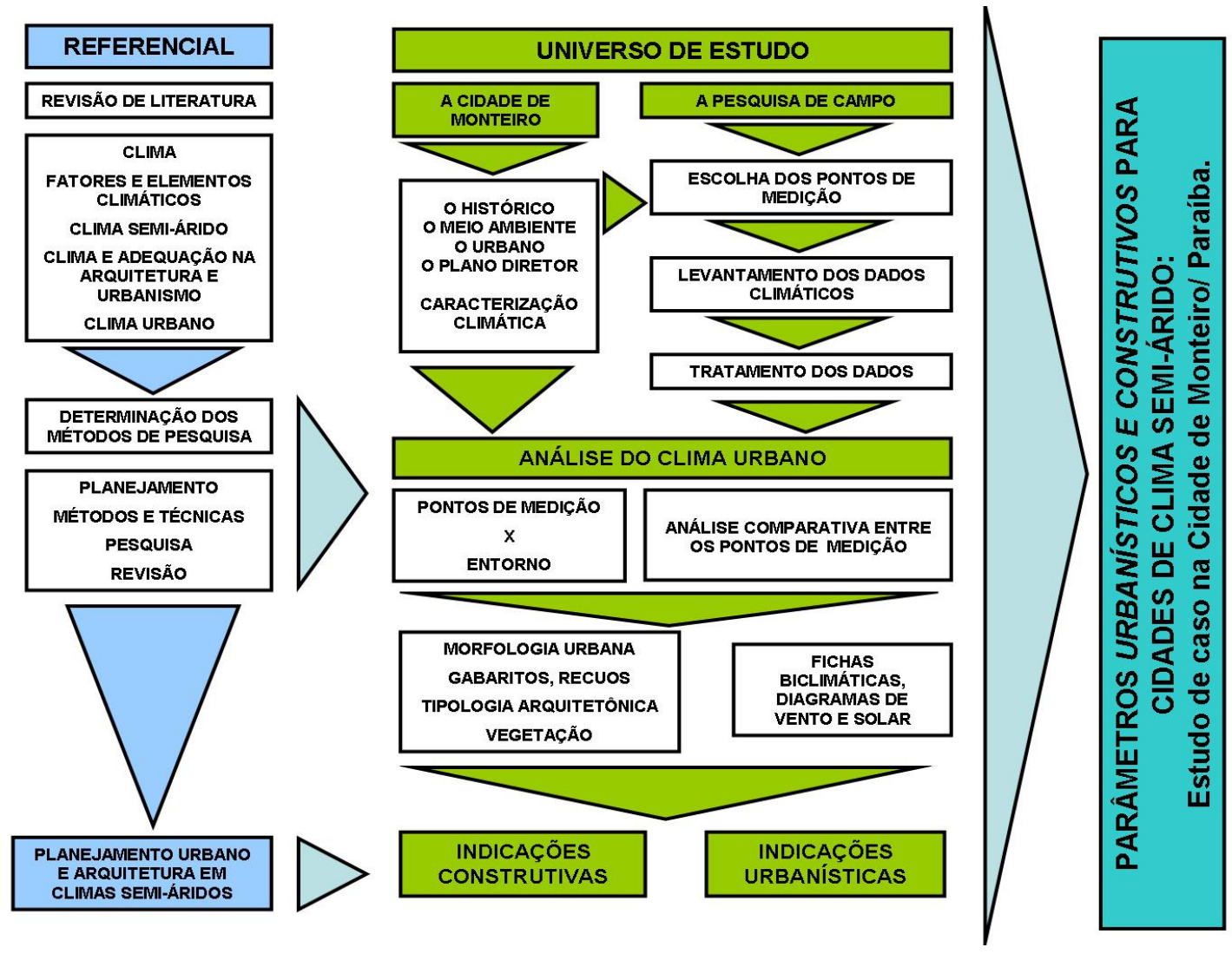

FIGURA 16: Fluxograma da pesquisa.

\section{Análise do Clima Urbano}

A Climatologia Urbana é uma linha de pesquisa necessária à compreensão do processo de urbanização, pois a "qualidade ambiental das nossas cidades está intimamente ligada a componentes climáticos, e, sobretudo, à ação antropogênica na geração dos inconvenientes e negativos climato-ambientais" (MONTEIRO, 1976).

Apesar dos esforços empreendidos nesta pesquisa, não foi possível utilizar os dados produzidos pela estação climatológica de Monteiro; a solução foi trabalhar com as informações da estação climatológica de Sertânia (PE), situada a 25 quilômetros. Assim, o estudo do clima urbano se deu a partir da comparação dos dados climáticos da Estação Agrometeorológica de Sertânia do INPE, PCD/CPTEC/INPE (2006) e os dados coletados na cidade de Monteiro por estações climatológicas portáteis. 


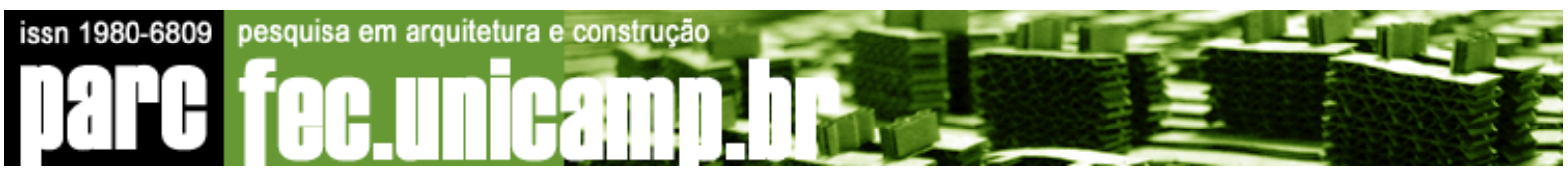

Seguindo esta metodologia, os dados climáticos coletados foram relacionados com os fatos específicos da própria condição urbana, de modo a promover "a comparação sincrônica e concomitante entre situações topo-climáticas distintas no universo urbano e as variações capazes de exibir as diferenças de atributos 'locais' e 'urbanos'” (MONTEIRO, 1976). Os dados climáticos foram relacionados com os atributos urbanos da cidade, considerando que Monteiro (1976), afirma:

A análise do clima urbano em geral e a do campo termo-dinâmico em especial, requer todo um material de caracterização da cidade: uso da terra, padrões de edificação com áreas verdes e espaços abertos, morfologia e estrutura urbana, configuração vertical, densidade demográfica, densidade de aparelhos de condicionamento interno de ar, intensidade do fluxo de veículos automotores e de pedestres, etc.

A variação diária dos elementos climáticos ao longo de um mês na cidade foi comparada à variação da estação de referência (Sertânia, PE). Esta comparação permite aferirem-se as 'constantes' devidas aos sistemas meteorológicos regionais e as 'variáveis' impostas pelas características 'locais'.

A observação climática em múltiplos pontos tem como objetivo revelar a dinâmica atmosférica em relação aos atributos topográficos e urbanos de cada local. Monteiro (1976) argumenta que:

(...) qualquer sistemática na técnica de análise no interior da cidade, (...), deve ser conduzida por uma ótica que revele o clima da cidade como algo que é produzido a partir de um fenômeno de transformação de energia num jogo integrado entre o ar atmosférico e o ambiente urbano edificado pelo homem.

A escolha dos pontos de medição recaiu em alguns locais seguindo a melhor forma de expressar a natureza ou o caráter peculiar da cidade. O critério de distribuição obedeceu à capacidade de revelar as seguintes informações:

- O caráter geoecológico do sítio sobre o qual se assenta a cidade, expondo as unidades morfológicas que nele se distinguem.

- A estrutura (morfologia + funções) urbana, tomada não como superposição, mas como 'integração' ao primitivo geoecológico.

- O dinamismo urbano representado por várias funções em sua morfologia.

Os pontos de medição foram dispostos ao longo de um eixo/transceto (eixo transversal), de modo a expressar as partes mais significativas da área de estudo e para compreender todo o complexo que é a cidade. A disposição dos pontos seguiu a cota decrescente de topografia, ficando o primeiro ponto no local mais alto da zona urbana e o último, ponto 05 , próximo à menor cota altimétrica encontrada da cidade. Entre o ponto 01 e o ponto 02 há 925 metros de distância. Entre os pontos 02 e 03, 645 metros, entre 


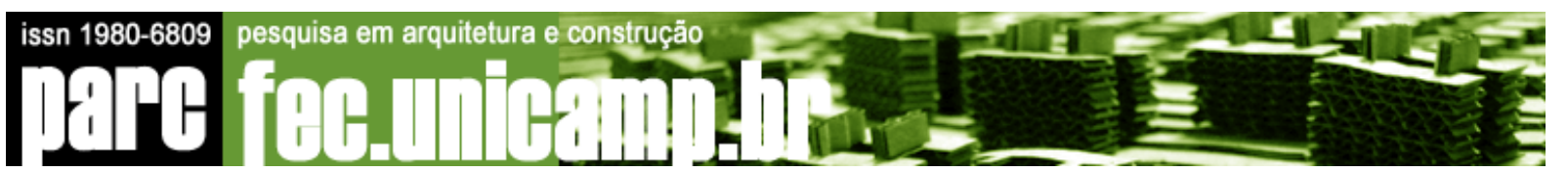

os pontos 03 e 04, 370 metros e entre os pontos 04 e 05, 195 metros. A Erro! Fonte de referência não encontrada.FIGURA 17 mostra a localização de cada ponto de medição e destaca a sua área de abrangência, ou seja, identifica as regiões próximas ao ponto escolhido que possuem características semelhantes (em laranja).

Cada ponto expressa - no momento em que foi registrado - o comportamento da atmosfera naquele dado ponto e está intimamente comprometido com as condições microclimáticas que a edificação urbana propiciou em larga escala. A comparação entre pontos diferentes através da estrutura da cidade, sondando suas partes mais expressivas, tem como objetivo revelar importantes fatos da natureza escalar meso e microclimática.

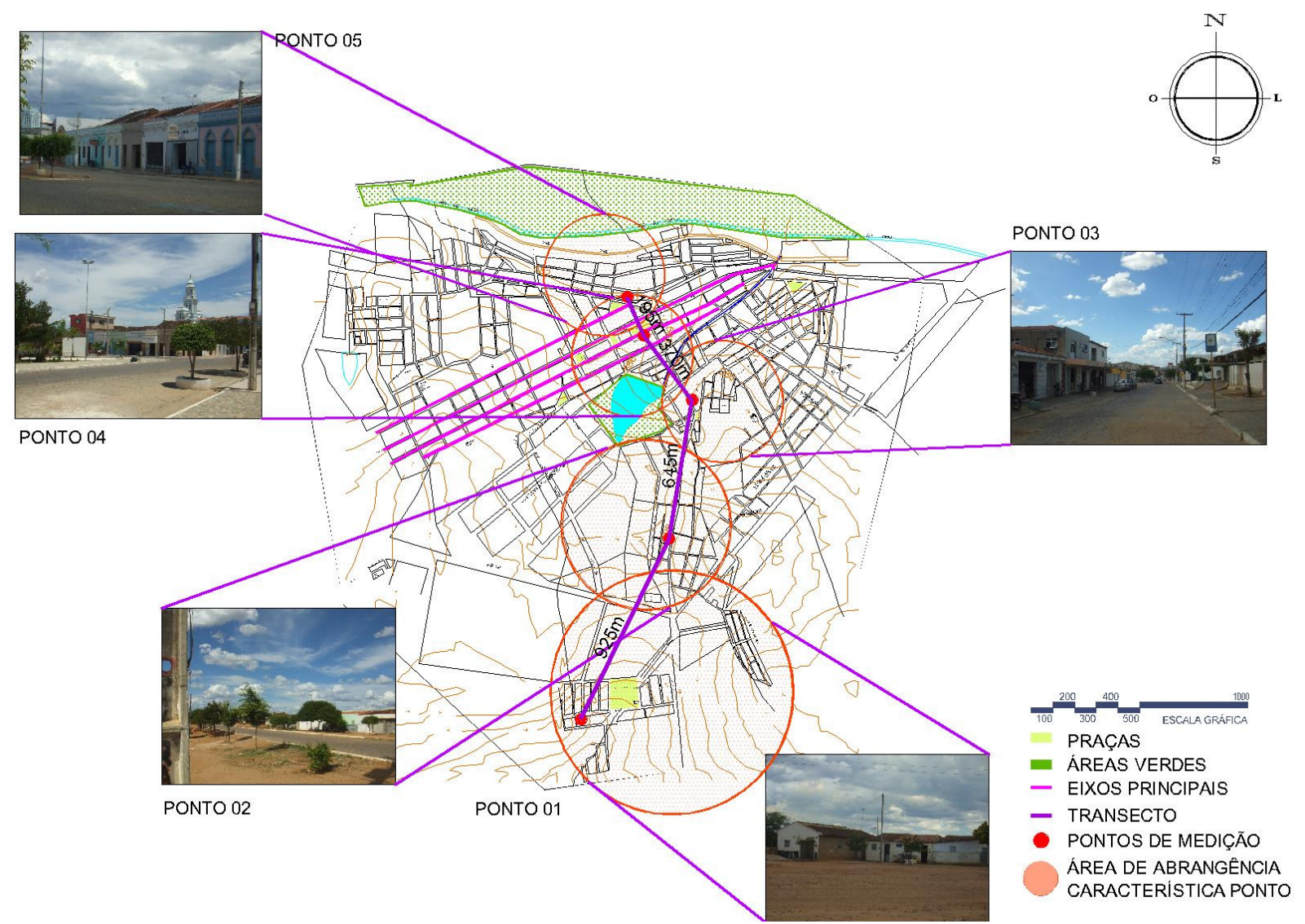

FIGURA 17: Mapa da Zona Urbana de Monteiro e os 5 pontos de medição escolhidos.

\section{Levantamento de dados climáticos no período de verão}

A coleta de dados teve início no dia 28 de outubro de 2006, com a instalação das estações climatológicas nos cinco pontos escolhidos, sendo os de medição externa fixados em um tripé de madeira e PVC com altura de 1,50 metros, confeccionado exclusivamente para este uso. O tripé ficou localizado na calçada próximo ao meio fio das ruas. Por estarem localizados em área pública foram prestados esclarecimentos sobre o 


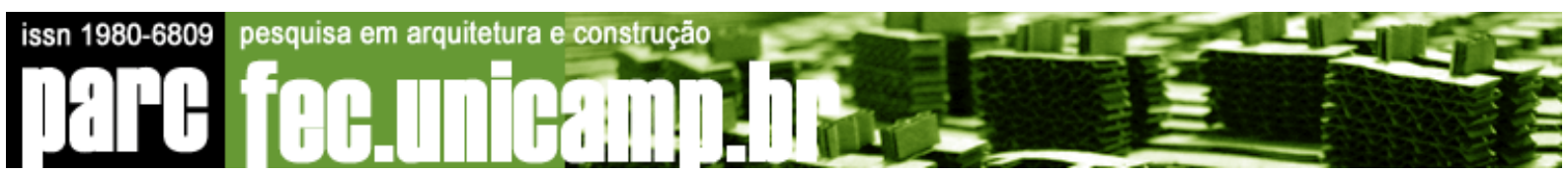

equipamento e as razões da pesquisa para os moradores de edificações próximas aos pontos, inclusive pedindo a colaboração para a manutenção e segurança dos equipamentos; um vigia noturno foi contratado para monitorar cada ponto de medição.

A base receptora ficou localizada na parte interna de edificações próximas aos pontos de medição, sendo programada para aferir e armazenar as variáveis ambientais a cada hora, durante todo o mês de novembro, resultando em 720 dados horários para cada ponto de medição. Os dados eram transferidos semanalmente para o computador e salvos no software heavyweather'. A rotina do experimento consistiu em coletar os dados (variáveis ambientais) internos e externos e transferi-los para um computador.

Durante os dias 29 e 30 de outubro foram realizados os testes necessários para assegurar que as medições iniciadas a partir da 00h00min do dia $1^{\circ}$ de novembro recebessem corretamente o sinal via rádio ou se seria necessária a utilização dos cabos.

\section{Imprevistos e incertezas experimentais}

Após os dois dias de teste verificou-se que todas as estações estavam funcionando corretamente, porém, ocorreram algumas falhas e alguns dados não foram coletados. Acredita-se que por algum erro na transmissão via rádio. Esse fato foi corrigido a partir da utilização do cabo que conecta os equipamentos externos com a base receptora. $O$ QUADRO 2 indica o período em que houve falha nas estações:

QUADRO 2: Dados não coletados pelas estações climatológicas.

\begin{tabular}{|c|c|c|}
\hline Ponto & Tipo de dado & Período \\
\hline \multirow{2}{*}{01} & Velocidade e Direção dos ventos & $\begin{array}{l}\text { 00h00min de } 01 / 11 \text { às } \\
23 \text { h00min de } 15 / 11\end{array}$ \\
\hline & Todos & $\begin{array}{l}12 \mathrm{~h} 00 \mathrm{~min} \text { de } 24 / 11 \text { as } \\
7 \mathrm{~h} 00 \mathrm{~min} \text { de } 30 / 11\end{array}$ \\
\hline \multirow{2}{*}{02} & Velocidade e Direção dos ventos & $\begin{array}{l}\text { 00h00min de } 01 / 11 \text { às } \\
23 \text { h00min de } 15 / 11\end{array}$ \\
\hline & Temperatura interna e externa & $\begin{array}{l}\text { 00h00min de } 01 / 11 \text { às } \\
23 \text { h00min de } 03 / 11\end{array}$ \\
\hline \multirow{3}{*}{03} & Velocidade e Direção dos ventos & $\begin{array}{l}00 \mathrm{~h} 00 \mathrm{~min} \text { de } 01 / 11 \text { às } \\
23 \mathrm{~h} 00 \mathrm{~min} \text { de } 15 / 11\end{array}$ \\
\hline & $\begin{array}{l}\text { Temperatura externa, sensação } \\
\text { térmica, temperatura de orvalho e } \\
\text { velocidade e Direção dos ventos. }\end{array}$ & $\begin{array}{l}\text { 7h00min de } 01 / 11 \text { às } \\
20 \mathrm{~h} 00 \mathrm{~min} \text { de } 03 / 11\end{array}$ \\
\hline & $\begin{array}{l}\text { Temperatura externa, sensação } \\
\text { térmica, temperatura de orvalho e } \\
\text { velocidade e Direção dos ventos. }\end{array}$ & $\begin{array}{l}14 \mathrm{~h} 00 \mathrm{~min} \text { às } 10 \mathrm{~h} 00 \mathrm{~min} \text { de } \\
25 / 11\end{array}$ \\
\hline \multirow{2}{*}{04} & Todos & $\begin{array}{l}00 \text { h00min de } 01 / 11 \text { às } \\
23 \text { h00min de } 03 / 11\end{array}$ \\
\hline & Velocidade e Direção dos ventos & $\begin{array}{l}00 \mathrm{~h} 00 \mathrm{~min} \text { de } 01 / 11 \text { às } \\
23 \mathrm{~h} 00 \mathrm{~min} \text { de } 15 / 11\end{array}$ \\
\hline 05 & \multicolumn{2}{|l|}{ Nenhum dado foi perdido. } \\
\hline
\end{tabular}




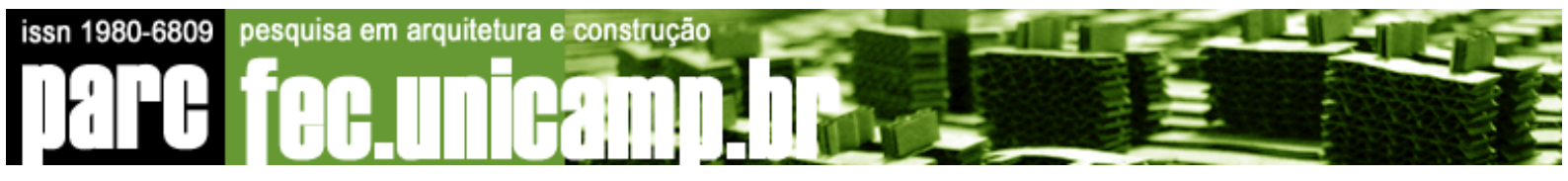

Deve-se ressaltar que algumas incertezas experimentais podem surgir por possíveis erros ocorridos durante os procedimentos em campo, como o manuseio incorreto dos equipamentos e alguma falha na calibração dos instrumentos. Além disso, utilizou-se somente uma única amostragem, uma vez que a repetição do levantamento não foi realizada por causa das restrições do cronograma da pesquisa.

Buscando minimizar os possíveis erros sistemáticos recorreu-se, na análise descritiva dos dados, ao cálculo das médias horárias das variáveis climáticas em cada ponto, eliminando assim algum possível desvio de padrão dos dados.

\section{Análise do clima urbano}

De um ponto de vista climatológico, o principal interesse desta pesquisa é mostrar o impacto da área urbana na atmosfera. No planejamento urbano e projeto de edificação o interesse maior está na direção oposta, ou seja, estudar os impactos da atmosfera urbana nos aspectos funcionais, econômicos e de segurança do ambiente edificado sobre a saúde e bem estar de seus ocupantes. Monteiro (1976) explica que, após a identificação dos impactos, devem-se desenvolver métodos para modificá-los. Esta necessidade de comparação justifica aqui a utilização dos referidos dados de Sertânia $(\mathrm{PE})$, por serem os dados climáticos da zona rural/natural mais próxima à cidade de Monteiro (PB). A estação agrometeorológica está localizada na Zona Rural de Sertânia e a $25 \mathrm{~km}$ da Zona Urbana de Monteiro. O município de Sertânia localiza-se a 558,00 metros de altitude em relação ao nível do mar e possui ambiente natural semelhante ao de Monteiro.

O experimento realizado na cidade, nele mesmo, já objetiva revelar as feições identificáveis no contexto local. Tanto pelas características topográficas (ou geoecológicas) do sitio, quanto pelas diferenças geradas pela própria estrutura urbana. Se a observação meteorológica padrão, restrita a um ponto, revela a resposta local a dinâmica atmosférica regional, no evento, a multiplicação dos pontos de observação - mensuração no universo local - visa à revelação dos atributos topográficos e urbanos neste contexto. Toda a qualquer sistemática na técnica de análise no interior da cidade, realizada pelo geógrafo, deve ser conduzida por uma ótica que revele o clima da cidade como algo que é produzido a partir de um fenômeno de transformação de energia num jogo integrado entre 0 ar atmosférico e o ambiente urbano edificado pelo homem. (MONTEIRO, 1976).

Deste modo, apresentam-se aqui as considerações acerca do clima urbano da Cidade de Monteiro, no que diz respeito às variáveis climáticas estudadas: direção e velocidade dos ventos, temperatura e umidade relativa; bem como outros aspectos verificados: intensidade de radiação solar e as configurações urbanas de cada ponto de medição. Quanto às velocidades dos ventos, tendo o valor médio medido em Sertânia no 
mesmo período de $6,90 \mathrm{~m} / \mathrm{s}$, verifica-se um decréscimo significativo da velocidade nos valores medidos na zona urbana de Monteiro (GRÁFICO 4).

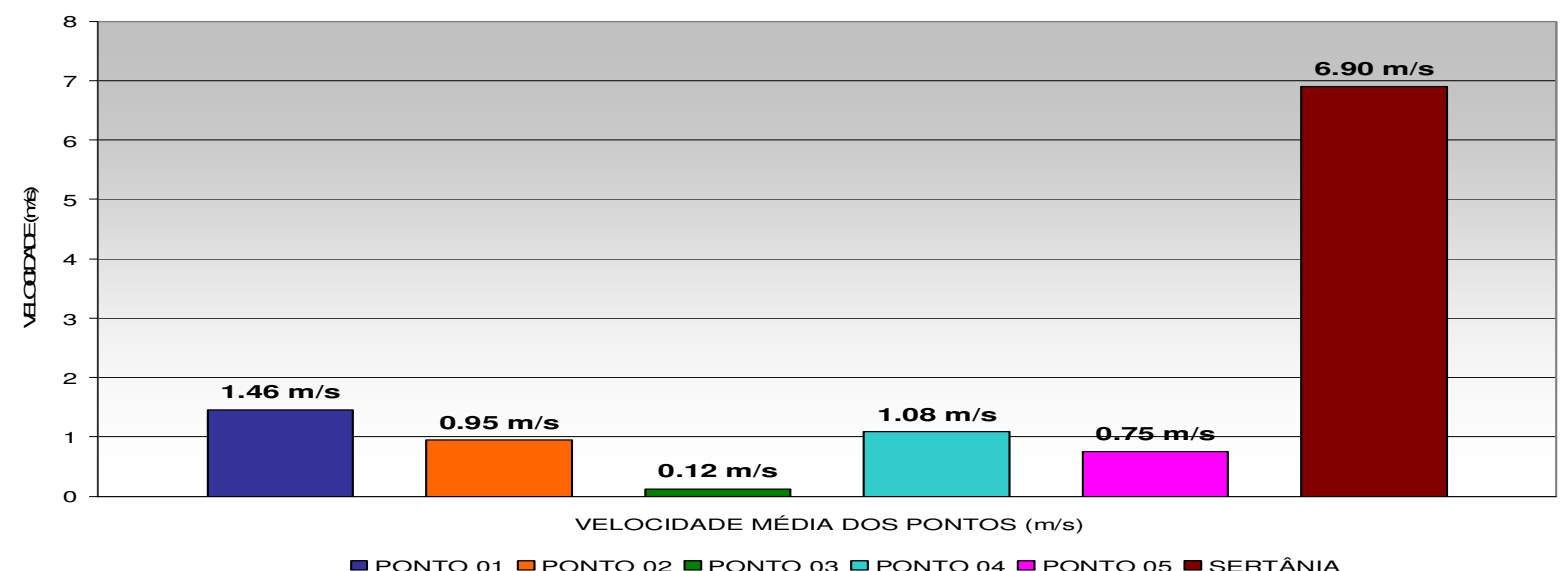

GRÁFICO 4: Velocidade média dos ventos (m/s) nos pontos de medição.

O GRÁFICO 5 apresenta as temperaturas médias do ar diárias, registradas durante o mês de novembro de 2005. Observando o gráfico pode-se verificar que os pontos $02 \mathrm{e}$ 04 foram o que apresentaram as menores elevações de temperatura em relação à estação de referência (Sertânia). Este comportamento confirma a influência da urbanização da alteração do clima da cidade como um todo e ainda aponta uma alteração maior nas regiões mais urbanizadas.

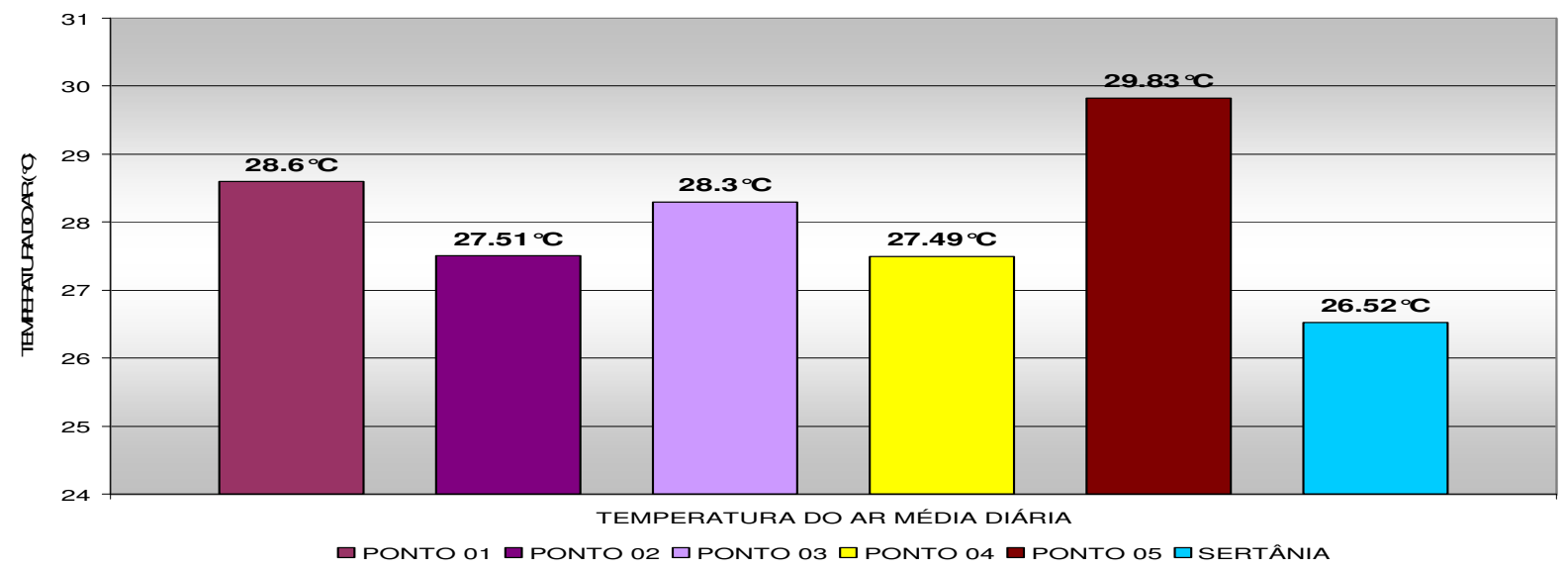

GRÁFICO 5: Temperatura média nos pontos em ${ }^{\circ} \mathrm{C}$ durante o mês de novembro de 2005.

Sabe-se que uma das características do clima quente-seco é uma grande amplitude térmica diária e a partir dos dados de referência essa característica é confirmada, verificando uma amplitude térmica do ar média de $14,25^{\circ} \mathrm{C}$. Na zona urbana de Monteiro, porém, os valores de amplitude térmica verificados indicam a interferência da urbanização no clima, pois se apresentam, em média, $4,72^{\circ} \mathrm{C}$ acima do valor medido em Sertânia. 


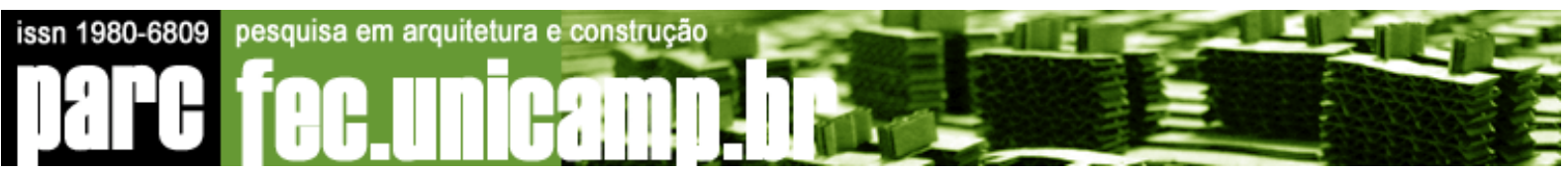

A amplitude diária da umidade relativa é alta, como se pode observar no GRÁFICO 6 , que apresenta os valores médios diários de umidade relativa do ar, média mínima e máxima, observados durante o mês de novembro de 2005.

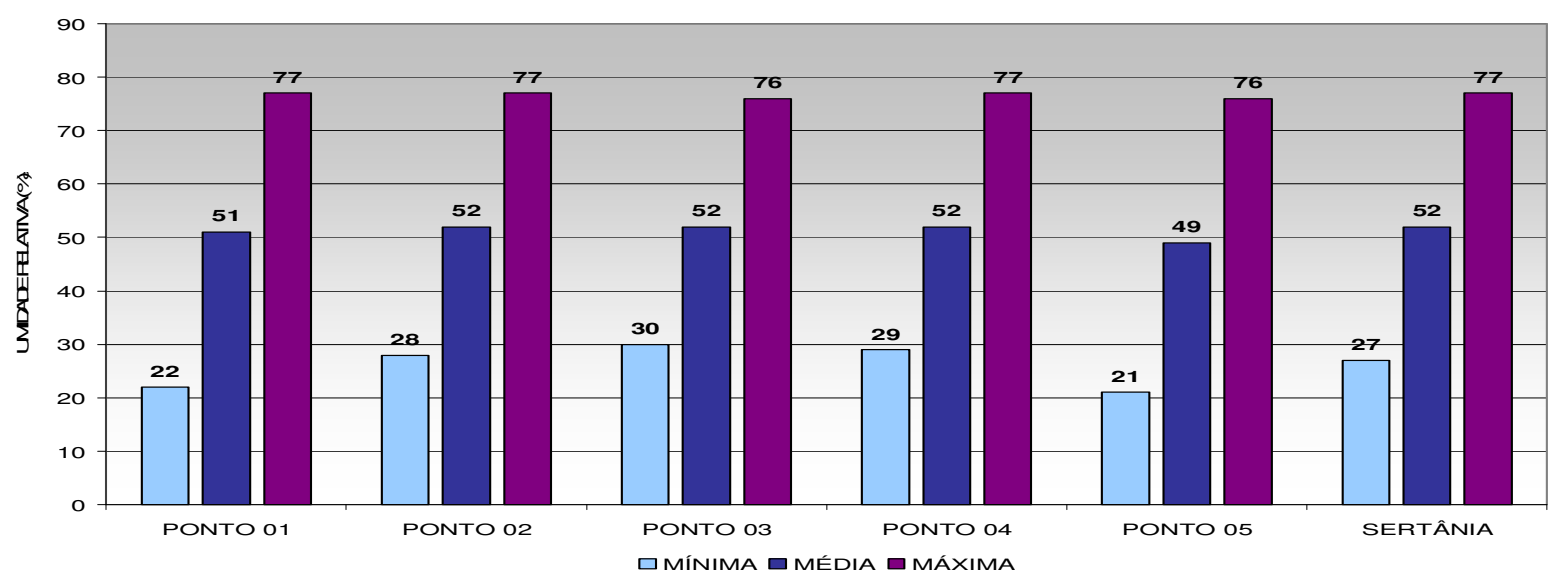

GRÁFICO 6: Valores médios da umidade relativa (\%) durante o mês de novembro de 2005.

Observando o comportamento da umidade relativa nos diversos pontos estudados e em Sertânia verificam-se valores muito próximos durante a madrugada até as 6 horas da manhã, no entanto, a partir das 7 horas a umidade relativa observada na zona urbana de monteiro decai enquanto que o valor de referência permanece alto. A umidade relativa medida em Sertânia começa a diminuir a partir das 11 horas, permanecendo mais alta que os pontos estudados. À noite, a partir das 18 horas, a umidade relativa na cidade aumenta, ultrapassando os valores verificados em Sertânia. A queda da umidade relativa durante o dia aponta a influência da urbanização, que diminui as áreas permeáveis, aumenta a temperatura, os índices de radiação e outras variáveis ambientais que afetam a umidade relativa.

\section{Diretrizes urbanísticas e construtivas para cidades de clima semi-árido}

Após analisar as configurações do clima urbano estudado e correlacionar os problemas que podem ter influenciado o clima em cada ponto de estudo, indicam-se, aqui, preliminarmente, algumas medidas que poderiam auxiliar na melhoria do conforto ambiental da cidade de Monteiro.

Verifica-se que em todos os pontos estudados deve-se tomar partido da ventilação noturna e manter as edificações protegidas do vento seco diurno. O ponto 01 e 002 são os mais abertos aos ventos, então, nessa região deve-se atentar para que, se houver verticalização, que esta possa manter a porosidade em relação aos ventos, construindo edificações com diferentes gabaritos, para que a rugosidade auxilie no aumento da velocidade dos ventos. Quanto aos ventos, no ponto 03, sugere-se que se crie uma 


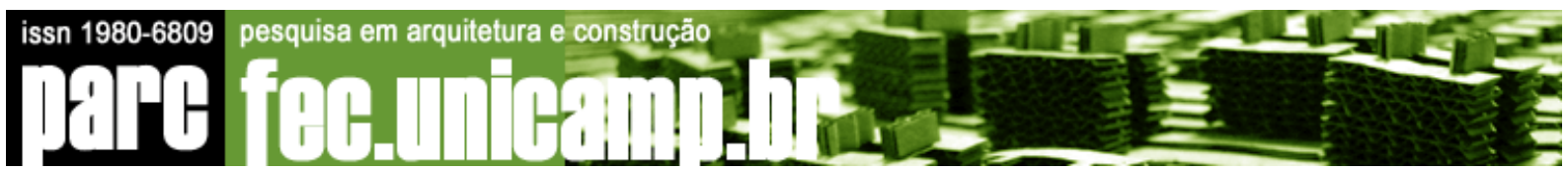

rugosidade maior para tentar aumentar a velocidade e o escoamento dos ventos, mas observando o índice de aproveitamento de 1,8 indicado pelo Plano Diretor do município.

A orientação das ruas principais nos pontos 01, 04 e 05, na direção oeste-leste, não é adequada, pois favorece muito a incidência da radiação solar na calha viária e nas fachadas das edificações. Sugere-se que para novas vias essa orientação seja evitada e para as vias existentes que se arborizem os canteiros centrais para diminuir a radiação incidente na calha viária; recomenda-se, também, o aumento do porte das árvores existentes localizadas em frente às fachadas das edificações e, no caso da ausência de vegetação em frente às edificações, que sejam plantadas espécies que favoreçam o sombreamento. As vias principais nos pontos 02 e 03 obedecem a uma adequada orientação, porém, deve-se arborizar as calçadas para evitar a radiação solar direta.

Ainda sobre a arborização, sugere-se a arborização da área pública existente na região do ponto 01, que se redistribuam as árvores na Praça João Pessoa, ponto 04, e que se aumente o porte da vegetação existente na Praça da Saudade, ponto 05. Tornase importante manter a permeabilidade das áreas públicas existentes no ponto 01 e $05 \mathrm{e}$ nas laterais da via principal do ponto 02 . Sugere-se um estudo para a redistribuição da área permeável da Praça João Pessoa, ponto 04 e para a criação de áreas verdes e espaços permeáveis na área do ponto 03.

Os pontos 01 e 02 estão localizados em áreas definidas pelo Plano Diretor como zona adensável, contudo, convém observar se este adensamento futuro não poderia criar uma barreira aos ventos. O aumento do adensamento deve ser evitado na região do ponto 03 e restringido nas regiões do ponto 04 e 05 .

Para novas edificações térreas pode-se utilizar a tipologia de casas geminadas, que protegem uma das fachadas laterais, mas mantendo um recuo para que se tome partido da ventilação noturna. Para edificações verticais deve-se atentar para o seu gabarito, principalmente para que estas não atuem como barreira dos ventos principais. Na figura 18 é apresentado um mapa síntese da região estudada e as principais diretrizes para cada ponto estudado. 

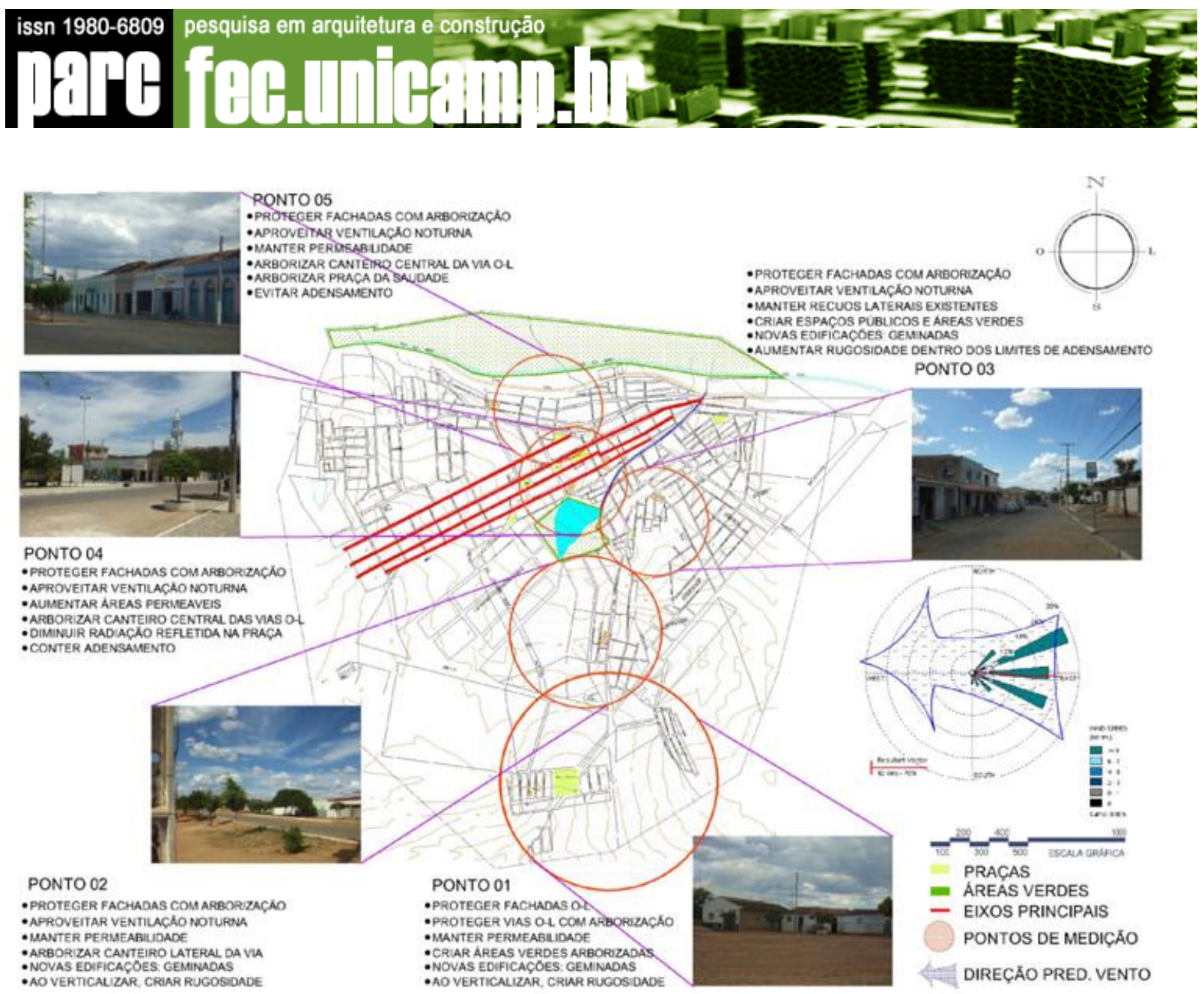

FIGURA 18: Croqui - Diretrizes Preliminares para Monteiro

A identificação dos ambientes climáticos na zona urbana de Monteiro comprovou a influência de sua urbanização na formação de condições desagradáveis ao desenvolvimento das atividades sociais humanas. Verificou-se que as variáveis do clima que devem ser controladas dizem respeito à insolação elevada, diferenças acentuadas de temperatura entre o dia e a noite, umidade relativa baixa e vento quente diurno.

A arquitetura e o urbanismo na cidade devem possibilitar, durante o dia, temperaturas internas abaixo das externas e durante a noite acima. A ventilação diurna não é útil, pois o vento externo está mais quente que a temperatura do ar interno, porém a ventilação noturna deve ser considerada.

As diretrizes propostas neste artigo correspondem ao conjunto de instruções ou indicações para serem consideradas durante o planejamento urbano e de projeto. Estas diretrizes deverão nortear as decisões, gerando soluções e recursos para supri-las. As diretrizes foram formuladas a partir da análise dos fatores e elementos climáticos e de indicações coletadas durante pesquisa de referencial teórico. Nesta pesquisa também foi aproveitada a experiência de um trabalho anterior (LIMA, 2005), realizado em um âmbito mais restrito no qual se propõem diretrizes para uma edificação específica localizada no 


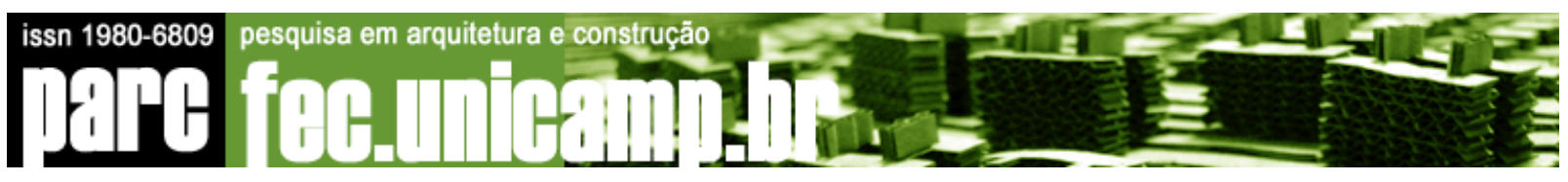

semi-árido, fato que permitiu o desenvolvimento deste referido estudo sobre Monteiro (PB)..

\section{Diretrizes Urbanísticas}

a) Implantação/Orientação. É indicada a orientação Norte ou Sul para as ruas de maior dimensão, criando calçadas sombreadas em um dos períodos do dia. No caso das vias principais existentes na cidade, que possuem orientação Leste-Oeste, estas devem ser arborizadas, com árvores de grande porte em seus canteiros centrais e no alinhamento das calçadas para que a vegetação proteja a via da incidência direta de radiação.

b) Ruas estreitas. Contribuem para a diminuição da incidência de radiação solar sob a calha viária, ângulo de incidência de sol menor, ocasionando mais períodos de sombra.

c) Pequenos traçados. As ruas não devem ter um traçado extenso e reto, e sim prever praças e desvios de modo a não canalizar os ventos.

d) Ampliação e criação de espaços verdes em toda a zona urbana. As áreas verdes trazem benefícios aos microclimas urbanos, principalmente por amenizarem a temperatura local, sendo excelentes condicionadores térmicos.

e) Arborização Urbana. As árvores podem ser utilizadas para interceptar os raios solares que incidem diretamente sobre as paredes da edificação, produzindo sombra sobre as fachadas e diminuindo, assim, os ganhos térmicos e o conseqüente aquecimento no interior das mesmas.

f) Incentivar o paisagismo adequado à região. Buscar a utilização abundante de vegetação de espécies de ciclo perene, alta rusticidade, resistência à exposição direta ao sol e baixa necessidade de manutenção (copa alta, baixa, arbustos, rasteira, trepadeira etc.), principalmente nas áreas Leste e Oeste.

g) Aumentar a permeabilidade das áreas verdes públicas/praças. Nota-se uma concentração de praças na região central da cidade, porém estas são extremamente pavimentadas. Devem-se criar novos espaços perenes em outros bairros da cidade.

h) Novas praças e áreas públicas. Sugere-se a criação de novas praças distribuídas em toda a zona urbana, visando uma re-arborização adequada, utilizando espécies de grande porte, que gerem sombra nas praças existentes. Indica-se a criação de espaços públicos em torno do açude público e das margens do rio Paraíba, criando ambientes agradáveis e umidificados, próximos às massas de água. 
i) Conter o adensamento na região central. As áreas centrais da cidade são extremamente urbanizadas criando microclimas desagradáveis. Nas áreas definidas pelo Plano Diretor como zonas adensáveis é imprescindível acompanhar o processo de urbanização para que o adensamento futuro não crie uma barreira aos ventos.

j) Verticalizar sem criar barreiras aos ventos. Se houver verticalização nas áreas permitidas na cidade, que esta possa manter a porosidade em relação a passagem dos ventos e que sejam construídos edifícios com diferentes gabaritos, para que a rugosidade auxilie no aumento da velocidade dos ventos.

k) Criar rugosidade em áreas com muita incidência de calmarias de vento. Sugere-se que se crie uma rugosidade maior em áreas de pouco vento, para tentar aumentar a velocidade e o escoamento dos ventos, mas observando os índices de aproveitamento indicados pelo Plano Diretor do município.

l) Evitar grandes afastamentos entre as edificações. Permitindo que estas façam sombra umas nas outras.

m) Criar espaços úmidos. Os espaços abertos podem conter espelhos de água, chafarizes ou outras soluções. A evaporação da água trará ao ar mais próximo uma maior sensação de conforto.

\section{Diretrizes Construtivas}

a) Implantação/Orientação. É indicada a orientação Norte ou Sul para as faces de maior dimensão das edificações; as fachadas Leste-Oeste devem ser projetadas com recursos que as transformem em barreiras térmicas. As faces orientadas em torno do Leste ou do Oeste devem ter a mínima dimensão possível. Devem-se proteger as faces externas da radiação provinda de Leste e Oeste.

b) Arborizar as calçadas. Evitando a radiação solar direta nas fachadas das edificações.

c) Aproveitar a ventilação Noturna. Deve-se tomar partido da ventilação noturna e manter as edificações protegidas do vento seco diurno.

d) Controlar ventilação diurna. Desejável ventilação sem entrada de radiação solar. Facilitar apenas a troca, sob controle, do ar interno às edificações evitando os ventos.

e) Proteger ao máximo as fachadas. Para novas edificações térreas sugere-se a utilização da tipologia de casas geminadas, com o intuito de proteger uma das fachadas laterais e manter um recuo, proporcionando a ventilação noturna. 
f) Manter permeabilidade no lote. Estipular limites para impermeabilização nos lotes, estimulando a criação de jardins e outras áreas vegetadas próximas à edificação.

g) Coberturas. As lajes, se forem utilizadas, devem ter grande espessura ou ser preenchidas de material que aumente sua inércia térmica ou as proteja da radiação solar (areia, terra com gramado, água, tijolo furado ou pedra argila expandida com água etc.). Desejável forro formando câmara de ar.

h) Paredes. De grande espessura e materiais pesados e maciços (tijolo, pedra, taipa, concreto etc.). Desejável parede dupla com câmara de ar fechada.

i) Pisos. Desejável que sejam absorventes e, nos casos de baixos valores de umidades, sejam umedecidos (tijolo sobre areia, cerâmicas porosas etc.).

j) Aberturas. Quanto às aberturas, as portas e janelas devem ser pequenas principalmente em fachadas, para que se proteja da radiação direta e refletida. Podem ser guarnecidas de persianas, treliças etc. e de vidro ou lâminas que permitam abertura. Desejável que sejam voltadas para pátios internos, para alpendres ou áreas sombreadas. Indica-se de $10 \%$ a $15 \%$ da área do piso.i

k) Adotar materiais com alta inércia térmica. Paredes e coberturas pesadas: transmitância $U \leq 2,20$ e atraso térmico $\varphi \geq 6,5^{\mathrm{iii}}$. Paredes em tijolo maciço (Adobe), taipa, pedra, tijolo furado com revestimento térmico. Paredes internas em tijolo maciço ${ }^{\text {iv }}$.

l) Diminuir poder de absorção das superfícies e aumentar o poder de reflexão. Superfícies externas com cores claras reflectante. Sugere-se também a utilização de coberturas abobadadas, pois esta forma facilita a re-irradiação durante a noite. Construções compactas também auxiliam a diminuir a absorção; as pequenas aberturas nas fachadas protegem a edificação da radiação direta e refletida.

Por fim, registra-se, aqui, a necessidade de que esta pesquisa e suas propostas sejam um instrumento para discussão, por meio da Prefeitura Municipal de Monteiro e de seus responsáveis, objetivando a implementação do Plano Diretor, além da necessária participação dos setores de projetos e fiscalização de obras, dentre outros, que atuem diretamente no ordenamento da cidade. Destaca-se também a importância da elaboração de um Código de Obras para o município que atenda as necessidades de adaptação das construções ao meio.

Considerando a impossibilidade de esgotar, neste artigo, todas as indicações e possibilidades de ocupação e construção, em áreas urbanas, adequadas ao clima semiárido, o objetivo proposto resume-se a estimular e contribuir para uma discussão, visando à criação de novas referências para as cidades localizadas nesta região. 
A experiência desta pesquisa, relatada resumidamente neste artigo, reafirma a necessidade de evitar, no semi-árido, a utilização de diretrizes construtivas, projetuais e de modelos urbanos provenientes de outras regiões com diferentes tipos climáticos, principalmente das regiões litorâneas, onde na maioria dos casos, se localizam as capitais dos estados nordestinos. Conclui-se que há a necessidade de aplicar ações que visem à sustentabilidade, a adequação ambiental, criando uma cidade saudável, ecologicamente equilibrada e, principalmente, adaptada ao meio ambiente em que se insere.

\section{Referências}

ABNT - Associação Brasileira de Normas Técnicas. Desempenho térmico de edificações

Parte 3: Zoneamento bioclimático brasileiro e diretrizes construtivas para habitações unifamiliares de interesse social. Projeto 02:135.07-001/3. Rio de Janeiro: ABNT, 2003.

ARAÚJO, Virgínia Maria Dantas de. Parâmetros de conforto térmico para usuários de edificações escolares no litoral nordestino brasileiro. Tese (Doutorado em Arquitetura). FAU/USP. São Paulo: 1996.

ATLAS climatológico do Estado da Paraíba. Campina Grande: Universidade Federal da Paraíba/ UFPB, Financiadora de Estudos e Projetos/FINEP, Banco do Nordeste do Brasil/BNB, 1987. 2ª Edição. SILVA, M. A.; SOBRAL, Z. Et al.

BERTALLANFFY, L. Von. Teoria Geral dos Sistemas. Petrópolis, Vozes, 1973.

BUSTOS ROMERO, Marta. Arquitetura Bioclimática do Espaço Público. Brasília: Editora UNB, 2001.

BUSTOS ROMERO, Marta. Princípios Bioclimáticos para o Desenho Urbano. São Paulo: Projeto, 1988.

CASTELLS, Manuel. La Question Urbaine. Paris: Ed. François Maspero, 1973.

FROTA, Anésia Barros. Manual de Conforto Térmico: Arquitetura e Urbanismo. São Paulo: Studio Nobel: 2003.

GIVONI, 1967. Climograma. Escuela Técnica Superior de Arquitectura de Madrid -Universidad Politécnica de Madrid -- Ministerio de Vivienda. Departamento de Urbanística y Ordenación del Territorio Redacción de una ordenanza ambiental Climograma de Olgyay Climograma de Givoni Ester Higueras| Madrid (España),

GIVONI, B. Confort Climate Analysis and Building Design Guidelines. Energy and Buildings, v.18, n.1, p.11-23. 1992. 
GRIMM, Alice Marlene. Meteorologia Básica - Notas de Aula: Prof. Alice Marlene Grimm. Primeira versão eletrônica - setembro 1999. Departamento de física UFPR. Disciplina Meteorologia Básica da Universidade Federal do Paraná. <http://fisica.ufpr.br/grimm/aposmeteo/> Acesso em 20.01.2007

LA CROSSE TECNOLOGY. Operation Manual Professional Remote Weather Station. Disponível em: <http://www.lacrossetechnology.com> Acesso em: 28.11.2006.

LIMA, Mariana Brito de. Casas Saudáveis em ambiente sustentável: Ecovila no Semiárido nordestino com ênfase na bioclimatologia e na sustentabilidade. Trabalho Final de Graduação (monografia). Curso de Arquitetura e Urbanismo da Universidade Federal do Rio Grande do Norte. Natal: Universidade Federal do Rio Grande do Norte, 2005.

LOMBARDO, Magda Adelaide. Ilha de Calor nas Metrópoles. Ed. Hucitec, São Paulo, 1985.

MARSH, A. WEATOOL, The Weather Tool: Climatic Visualizations and Design Analysis. Perth, Australia 1991.

MASCARÓ, Lucia. Ambiência Urbana. Porto Alegre: +4 Editora, 2004.

MONTEIRO, C. A. F. Clima Urbano. São Paulo: Contexto, 2003.

MONTEIRO, C. A. F. Teoria e clima urbano. Série "Teses e Monografias n 25", São Paulo, Instituto de Geografia da USP, 1976.

OLGYAY, V. Design with climate: bioclimatic approach to architectural regionalism. Princeton, N.J.: Princeton University Press, 1963.

PCD/CPTEC/INPE. Plataforma de coleta de dados meteorológicos, hidrológicos e ambientais da estação agrometeorológica de Sertânia. Dados Climáticos de Sertânia, mês de Novembro de 2005. Disponível em: <http://tempo.cptec.inpe.br:9080/PCD/>; < <http://pyata.cptec.inpe.br:8080/pcd/ consulta_pcda.jsp>;<http://pyata.cptec.inpe.br:8080/pcd /passo6.jsp dados sertânia 2007INPE /CPTEC> Acesso em : 20.02.2007; 20.03.2007.

ROAF, Susan. Ecohouse: a casa ambientalmente sustentável. Porto Alegre: Bookman, 2006.

\section{Notas}

\footnotetext{
${ }^{1}$ Heavyweather - Um software elaborado para a leitura dos dados coletados na estação, desenvolvido pelo fabricante das estações portáteis la-crosse technology, que auxiliou na transferência dos dados da base receptora e a formatação inicial dos dados.

ii ABNT, 2003.

iii Idem.

iv lbidem
} 